NBER WORKING PAPER SERIES

\title{
OHIO SCHOOL MILK MARKETS: \\ AN ANALYSIS OF BIDDING
}

Robert H. Porter

J. Douglas Zona

Working Paper 6037

\author{
NATIONAL BUREAU OF ECONOMIC RESEARCH \\ 1050 Massachusetts Avenue \\ Cambridge, MA 02138 \\ May 1997
}

This paper is adapted from our reports and statements on behalf of the plaintiff in State of Ohio vs. Louis Trauth Dairies, Inc. et al. The case was settled before it came to trial. We received helpful comments from Tim Bresnahan, Lou Guth, Wick Heath, and Bernie Reddy, as well as from the participants in seminars at Boston University, Harvard, Stanford and U.B.C: This paper is part of NBER's research program in Industrial Organization. Any opinions expressed are those of the authors and not those of the National Bureau of Economic Research.

(C) 1997 by Robert H. Porter and J. Douglas Zona. All rights reserved. Short sections of text, not to exceed two paragraphs, may be quoted without explicit permission provided that full credit, including $(\subset$ notice, is given to the source. 
Ohio School Milk Markets: An Analysis of Bidding

Robert H. Porter and J. Douglas Zona

NBER Working Paper No. 6037

May 1997

JEL Nos. L13, L41, L66

Industrial Organization

\begin{abstract}
We examine the institutional details of the school milk procurement process, bidding data, statements of dairy executives, and supply characteristics in Ohio during the 1980's. We compare the bidding behavior of a group of firms to a control group. We find that the behavior of each of the firms differs from that of the control group. We argue that the behavior of these firms is consistent with collusion. The estimated average effect of collusion on market prices is about six and one half percent, or roughly the cost of shipping school milk about 50 miles.
\end{abstract}

Robert H. Porter

Department of Economics

Northwestern University

Evanston, IL 60208

and NBER

r-porter@nwu.edu
J. Douglas Zona

National Economic Research Associates 50 Main Street

White Plains, NY 10606 


\section{INTRODUCTION}

Sometime between May and August every year, school district officials throughout the country independently solicit bids on annual supply contracts for milk and other products. In response to these solicitations, dairies that are in a position to supply school milk submit bids on these procurement contracts. Typically, the low bidder is selected to supply milk in half pints to the schools during the following school year. As we describe below, the details of the procurement process, the nature of milk processing and delivery, and the characteristics of demand for school milk are such that collusive agreements among suppliers may be relatively easy to reach and maintain. Collusion appears to be a pervasive phenomenon in school milk auctions. ${ }^{1}$ There have been recent investigations of price fixing in auctions for the provision of school milk in more than twenty states. Guilty pleas have been entered in at least a dozen states, and fines levied in excess of $\$ 90$ million. About ninety people have been sent to jail, for six month sentences on average.

In State of Ohio vs. Louis Trauth Dairies, Inc., et al., the State of Ohio charged thirteen dairies with collusion in school milk auctions for the years 1980 through 1990 inclusive. As part of that case, bidding data were collected from school districts around Ohio. Statements from bidders, school district officials, and dairy officials were also gathered. In this paper, we examine the information collected as part of the case. We discuss whether the behavior of some of the firms operating in school milk markets around Cincinnati, Ohio is more consistent with competition or collusion. ${ }^{2}$

\footnotetext{
${ }^{1}$ See, for example, Henriques and Baquet (1993).

${ }^{2}$ In a forthcoming paper we discuss collusion in school milk auctions in the eastern part of Ohio.
} 
Collusion is an arrangement among a group of firms that is designed to limit competition between the participants. There are many alternative methods of colluding in auction markets. ${ }^{3}$ For example, conspirators could refrain from bidding against each other, say by allocating exclusive territories. Alternatively, they could submit several bids at inflated levels, where the number of bids may be intended to create the appearance of competition. In either event, the members of the ring know that competition has been limited in the affected markets. Any of these firms know that if they submit a bid they do not have to worry about being undercut by another ring member. Observed bids will differ from competitive bidding because the conspirators have coordinated their actions. The expected winning bid will be higher because conspirators have coordinated their actions, whether or not a conspirator wins the auction.

We examine institutional details of the procurement process for Ohio school milk auctions in the 1980's, bidding data, testimony of the executives of some dairies, and supply characteristics. Our econometric analysis focuses on the decisions by a dairy whether to submit a bid to supply milk to individual school districts, and on the level of submitted bids. We examine the bidding data for a group of firms that were not named as defendants in that case, and the estimated econometric models are generally consistent with competitive bidding. When we apply the same econometric models to the bid data for each defendant, we observe systematic deviations between predicted and realized bids. We investigate the nature of the deviations and find that they are consistent with the conspiracies alleged by the State.

We provide evidence that the bidding behavior of the accused dairies was more consistent

\footnotetext{
${ }^{3}$ Hendricks and Porter (1989) describe several collusive mechanisms, and why the detection of collusion is necessarily case specific.
} 
with collusion than with competition. For example, several of the defendants exhibit patterns of both local and distant bid submissions. That is, they submit bids relatively near their plants and they also submit bids well beyond their local territories. Further, our econometric analysis of bidding levels shows that the distant bids by the defendants tend to be relatively low. In contrast, distant non-defendant bids are an increasing function of the distance from the school district to a firm's nearest plant. These features of bidding by the defendants are consistent with territorial allocation of districts close to the dairies' plants and relatively competitive bidding at more distant locations, which were perhaps outside the area of territorial allocation. If bidding for local districts had been competitive, local bids should have been lower than distant bids, because shipping costs were lower and because the Cincinnati area has many potential local suppliers.

The paper is organized as follows. We describe in Section II the demand and cost characteristics of Ohio school milk markets. We argue in Section III that there were strong economic incentives to collude during the alleged period of conspiracy. We describe the milk procurement rules, and argue that a number of characteristics of the auction mechanism facilitated collusion. We discuss the nature of possible collusion in these markets given the statements of market participants and the institutional details. We then present in Section IV a model of competitive behavior in these school milk markets. We focus on the two interrelated decisions that a competitor would make: where to bid and at what level. In Section V we focus on the behavior of the defendant firms operating in the Cincinnati area. We find that the behavior of these defendant firms differed from that of a hypothetical control group firm. We find that the pattern of deviations from average control group behavior was consistent with the collusive scheme described by market participants. Finally, in Section VI, we estimate that collusion 
caused school districts to over-pay for school milk by about six and one half percent in the affected area during the period analyzed.

Our analysis extends a recent empirical literature on the detection of bid rigging. Porter and Zona (1993) describe bid rigging in New York State highway paving jobs on Long Island in the early 1980's. A subset of firms is known to have participated in pre-auction meetings in order to assign low bid privileges for specific contracts. The conspirators often submitted complementary or phony bids above their low bid, perhaps to create the appearance of competition. We compare the bids of firms not participant to these meetings to those of the conspirators. We show that the ranking of non-participant bids for individual contracts is correlated with cost measures such as capacity and capacity utilization, whereas the rank distribution of conspirator bids is not correlated with the same cost measures. In particular, bids higher than the conspirators' low bid are not correlated with the cost measures, consistent with a complementary bidding scheme. We focus on bid rankings within a contract, rather than bid levels, because we do not have access to contract-specific information. In contrast, the Ohio school milk data set we employ here contains information about the school districts, as well as information concerning individual contract terms.

Pesendorfer (1996) examines school milk bidding data from Florida and Texas. His data are from concluded cases, and his focus is on the differences between strong and weak cartels, where the distinction refers to whether or not side payments were made. He argues that the bidding data are consistent with the operation of a strong cartel in Florida and a weak cartel in Texas, in accordance with trial evidence. In contrast, our goal here is to distinguish between competitive and collusive bidding. Hewitt, McClave and Sibley (1996) also analyze the Texas 
data, and they conclude that there was collusion in the Dallas-Ft. Worth region.

The papers by Baldwin, Marshall and Richard (1995) and Bajari (1996) compare strucutral models of collusive and noncooperative bidding for Forest Service timber contracts and Minnesota highway improvment jobs, respectively. In both cases, a specific model of collsuion is considered. Our approach employs reduced form methods, and infers collusion from suspicious departures from competitive bidding patterns. The nature of the departures governs our inferences about the likely form of collusion.

\section{THE MARKET}

Market outcomes are determined by three factors: the nature of demand, the nature of the production process and the nature of competitive interaction among suppliers. In the current analysis, demand and cost characteristics are relatively easily described. The more difficult problem is determining the nature of competitive interaction given the demand and cost characteristics; that is the focus of a subsequent section.

There are more than 600 individual school districts in the State of Ohio. Most districts award annual contracts for the supply of school milk. Generally, each district annually and independently solicits bids for certain types of milk between May and August for the following school year. For example, a district will indicate that it expects to purchase 50,000 half pints of whole white and 30,000 half pints of whole chocolate milk. (This corresponds to a student population of about 450.) Firms that elect to bid submit a list of prices for the various products. In addition to specifying categories of milk, the district may require their supplier to provide coolers (for the refrigeration of milk), straws or napkins. Escalator clauses with price indexed to the price of raw milk are also provided in some bid requests, to reduce the risk to the dairy 
associated with submitting a bid on an annual contract, since the price of raw milk could fluctuate substantially over that period.

Demand for school milk is relatively insensitive to the price charged. We estimate the responsiveness of school districts' demand for milk to the price paid using cross section data obtained from the Ohio Department of Education. ${ }^{4}$ Price is not a statistically significant determinant of the demand for milk, despite substantial variations in price. If school district purchasing behavior does not respond to price increases, a firm that controls the supply of milk for a particular district could command a substantially higher price in that district.

Dairy processors receive raw milk from dairy farmers in the area. The price charged for raw milk is typically regulated through an elaborate system based on location and the type of milk. Although some milk producers are unregulated, the market would tend to produce a single price for both regulated and unregulated raw milk in the long run. The cost of the raw milk contained in a typical half pint purchased by a school district is about seven cents. (This figure varies seasonally and from year to year.) Raw milk is processed by standardizing the butter fat content (i.e., two percent or skim milk), pasteurized, packaged and delivered. Typically, potential suppliers of school milk pay about the same amount for raw milk, and they use much the same technology to pasteurize, package and deliver. As described below, we would expect incremental costs to be similar across different suppliers or potential suppliers. Any differences

\footnotetext{
4 We employ a sample of 609 school districts during May 1990. We find no significant effect of price on demand. We regress the logarithm of total half pints of milk purchased in 1990 on the size of the district, as measured by the logarithm of 1993 student enrollment, and the logarithm of price, standardized (by the method described below) to whole chocolate, in cents per half pint. The results are (t-statistics are displayed below the estimated coefficients in parentheses):
}

$$
\ln \text { (quantity) }=2.69+1.029 * \ln (\text { enrollment })+0.21 * \ln \text { (price) }
$$


in long run incremental costs would likely arise from differences in distance from the plant to the district.

When bids are solicited by school districts, firms in a position to supply will submit a bid. Which firms are in a position to supply the district? First, the firm must have access to a supply of school milk. The potential suppliers of school milk fall into one of two categories: processors, which process and package raw milk in the half pint containers demanded by the schools; and distributors, which often purchase milk wholesale from the processors and resell it to a school district. ${ }^{5}$ For any firm interested in selling its own milk in school milk markets, the costs of a processing plant may represent a substantial entry barrier. For those processors for which we have data, the school milk business represents a small fraction of their total revenues, typically less than ten percent. Although a processing plant is necessary to process school milk, school milk is only one of the products that would be produced in the plant. To our knowledge, no firm has ever built a processing plant solely to supply school milk. Thus the decision to build a plant hinges on considerations in other product markets such as supplying wholesale to supermarkets or to other institutions such as restaurants. (It should also be noted that there was substantially more exit than entry of processing plants during our sample period.) The costs of the processing plant that are directly attributable to school milk are therefore quite small. We conclude that only those firms that have access to a milk processing plant, largely put into operation for other

\footnotetext{
${ }^{5}$ There are many distributors active in Ohio school milk markets, but the relationship between processors and distributors can be classified into relatively few categories. First, some distributors are granted exclusive territories by a processor and offer bids using the affiliated processor's name or stationary. Second, some distributors purchase milk wholesale from one or more processors and sell it to schools using their own name. These distributors often switch processor affiliations from year to year, presumably to get better terms. Finally, although not as often, distributors can provide milk delivery to the processor for a delivery fee. Since all three arrangements coexist in the market, any particular type of distributor/processor relationship is unlikely to convey a competitive advantage.
} 
reasons, would have the ability to enter the school milk business selling their own product. ${ }^{6}$

If a firm has a plant that is relatively close to the school district in question, what costs would be incurred should the firm submit a bid and win the contract? First, are there any important fixed costs associated with serving school districts? Because data on the fixed costs of supplying school milk are not available, we analyze the size distribution of firms in the Ohio school milk business. For those companies participating in Ohio school milk markets, the scale of operations ranged from one firm supplying milk to about one percent of Ohio public school students annually to another that supplied milk to about seven percent of the Ohio public school students. The fact that firms that produce on vastly different scales coexist in these markets, even though marginal costs seem to be quite similar, indicates that the fixed costs associated with the school milk business for a dairy serving other customers may be relatively small.

Given that a firm has a plant and is in the school milk business, there are incremental costs associated with starting service to a new school district, such as the costs associated with providing a cooler or straws and adding the district to existing delivery routes. The delivery portion of total incremental cost may also be related to the number of deliveries per week for the new district and how well it fits with the firm's existing route structures. ${ }^{7}$ There are three main options for delivery: some dairies have dedicated school milk routes; others add school deliveries to their regular retail commercial routes; and other dairies use local delivery subcontractors for these services. Frequently, a dairy will utilize more than one option. Of course, delivery costs

\footnotetext{
${ }^{6}$ As noted earlier, firms can and do enter the market for the distribution of another firm's processed milk. Thus, the entry barriers into the school milk distribution business would be lower.

7 Absent collusion, bidders will not know exactly which school districts they will ultimately serve when they bid on individual contracts.
} 
vary with distance. A typical delivery cost is on the order of a penny per half-pint.

The cost of coolers is small relative to the other costs of school milk. For example, a 16case cooler can be purchased currently for $\$ 1,100$. Using an eight-year depreciation schedule, which probably underestimates a cooler's useful life, this figure implies a cost of about 0.2 cents per half-pint for a cooler that chills approximately 70,000 half pints per year. Finally, many firms use the same suppliers of packaging materials and typically pay about two cents per half pint for packaging.

To summarize, the cost of ingredients for a half pint of milk is on the order of about seven cents per half pint, packaging costs are about two cents per half pint and delivery costs to serve a school district are about one cent per half pint. Total delivered incremental costs are on the order of ten cents per half pint during the period analyzed. We expect these incremental costs to be independent of the scale of operations and similar across firms (after accounting for

proximity). Fixed and other one-time costs will affect a dairy's decision whether to enter or exit the school milk business, whereas the incremental costs of supplying an additional half-pint of milk or servicing another district are relevant for its pricing decisions.

\section{The Nature OF Possible Collusion}

The market characteristics described so far suggest competition among firms producing a homogeneous product with similar and constant incremental costs. Firms are likely to have good general information about the costs of their competitors, since most cost changes affect all firms similarly. There are unlikely to be substantial informational advantages in the market. School districts would be willing to pay high prices for school milk, if they had no other choice. Competition is likely to be localized, both because of the regulation of raw milk prices and 
because of relatively high transportation costs.

There are many features of Ohio's school milk markets that may affect the dairies' competitive interaction. Specifically, there are a number of characteristics that facilitate collusion. ${ }^{8}$ Firms compete only on price. Under the terms of the contract, the winning bidder supplies the demanded product with specified characteristics (e.g., butter fat content or flavoring). A cartel need only coordinate submission and bid decisions, and not other characteristics of the product, which simplifies the operation of a cartel. The policy of publicly announcing bids and the identity of the bidders allows cartel members to detect deviations from cartel agreements. Undercutting and cheating on collusive arrangements would not go unnoticed, and a collusive arrangement is more likely to be stable. Most school districts held their auctions annually but at different times during a year, and they acted on their own. ${ }^{9}$ The disorganized letting of contracts (as opposed to all contracts being let on a particular day, for example) allows cartel members to adjust bidding behavior during the season to allocate market shares, and it provides an opportunity for nearly immediate retaliation for bad cartel citizenship. The predictability of the demand for school milk from year to year allows threats of future retaliation in response to deviations to be credible. The fact that the markets themselves are easily defined according to school district boundaries permits allocations by assignment of territories. The set of firms potentially submitting bids in a particular market is small and quite stable. These firms use similar production processes and therefore face similar cost structures.

\footnotetext{
${ }^{8}$ These characteristics are also prevalent in other markets. See, for example, our 1993 paper on the detection of bidrigging.

${ }^{9}$ Some school districts occasionally band together in cooperatives and solicit bids for the group. However, cooperative arrangements historically have not prevented districts from soliciting bids individually.
} 
The similarity of potential suppliers makes it more likely that a group of firms could agree on joint behavior.

The same dairies encounter one another in more than one market, and so competition may not be fierce. ${ }^{10}$ Contact between competitors in multiple markets (school districts as well as wholesale accounts) makes collusive schemes that allocate markets more feasible. The practice of obtaining competitors' price lists through retail customers (e.g., grocery stores) was common, if not universal. Advance notification of list price increases can lead to supra-competitive prices: the practice allows communication of intentions to competitors (Holt and Scheffman, 1987).

Dairies are frequently customers of one another. This facilitates direct communication and allows a pretext for meetings between competitors. The practice allows communication of pricing information (even for products that are not purchased) through full price lists. Holt and Scheffman (1988) condemn this practice as potentially facilitating collusion.

The many dairy trade associations in Ohio allow a pretext for meetings of competitors. Examples include the Ohio Dairy Products Association, the Dairy Council of Ohio, the Mid-East Dairy Association and the Ohio Dairy Retail Association. Most are trade associations that meet on a regular basis to discuss issues of mutual interest. These associations obviously understand the legal dangers since the minutes of these meetings often indicate that the associations begin by reading a statement warning its members not to discuss prices.

Price decks were often used. Districts were assigned to a small number of price categories -- levels in the price decks. This practice can facilitate collusion since it makes

\footnotetext{
${ }^{10}$ Bernheim and Whinston (1990) examine how multimarket contact in a repeated market setting may affect firms' incentives and behavior. They conclude that "...multimarket contact relaxes the incentive constraints that limit the extent of collusion."
} 
complementary bidding easier. One level of the price deck can be for complementary bids that have no possibility of winning.

In 1993 representatives of two dairies operating in the southwestern part of Ohio confessed to rigging bids during the period we analyze. These individuals testified that they had rigged bids with other firms in the area (some of whom maintained their innocence). Their testimony was offered as part of a settlement of the criminal and civil cases against these firms (and perhaps individuals). Some of the testimony apparently contradicted earlier sworn testimony where these individuals maintained their innocence. The bid rigging scheme described in their testimony was one of respecting incumbencies. If one of the cartel members had served a particular school district in the previous year, then other firms were to submit high complementary bids that were sure not to undercut the incumbent firm's bid, or else refrain from bidding. The testimony described frequent communication among these competitors, as the specific details of the scheme were worked out through the bidding season. The individuals testified that there was a breakdown in the cartel in two school years, 1983-84 and 1989-90.

- Notwithstanding the testimony, a cartel among firms operating in the area is plausible and would be to the benefit of each of the participants. Since competition is localized, prices will fall to competitive levels only in areas where there is a sufficient number of local competitors. Distant competitors are disadvantaged by transportation costs and can only limit price increases to a certain extent. The competitive significance of each supplier is directly related to their relative distance from the school district. Any elevation of price that is achieved through collusion could, in some circumstances, be defeated by the entry of new firms from outside the market. In the case of school milk, entry will not take the form of a new firm setting up a 
processing plant; instead, it will be in the form of bids from firms whose plants are farther away. In this way, the transportation cost for distant non-cartel entrants will constrain the ability of a cartel to raise prices, but if collusion is effective then prices could be elevated by a significant amount. If local firms could coordinate their bidding behavior, then some profits could be earned without stimulating entry from distant suppliers. The reaction of any school district is unlikely to limit the ability of a cartel to raise price. As noted above, demand for school milk is inelastic and school districts would continue to purchase milk even at elevated prices, to the detriment of the school districts and to the benefit of cartel members.

A scheme of respecting incumbencies is one way for a cartel to coordinate bidding behavior. Such a scheme would be attractive if cartel firms were near each other (as some are in this case). The mechanism avoids the cartel problem of allocating school districts of varying profitability (because some are further away or otherwise require more service) among the cartel members. Another way of coordinating bidding behavior would be the assignment of geographic territories to individual firms. Territorial assignment would be a more practical collusive mechanism when firms are geographically separated, and some firm has a clear advantage in serving a particular district.

\section{A MODEL OF COMPETITIVE BEHAVIOR}

In a competitive market, firms in the school milk business face two interrelated decisions. First, should the firm submit a bid in a particular district? Second, if a bid is submitted, what should the bid level be? We address these decisions in turn in the sub-sections below. Here we describe a reduced form model of competitive bidding. 
We estimate a reduced form model of bidding behavior ${ }^{11}$ using a data set provided by the State of Ohio that contains information on school milk procurement for as many as 509 of the approximately 600 school districts in the state from 1980 through 1990, inclusive, with approximately 60 different bidders participating at some point in the sample. Table 1 provides some descriptive statistics for each year in our sample. We create a control group comprised of non-defendant firms that bid on Ohio school milk contracts. The data set contains information on the identity of the districts, their location and enrollment, and the timing of contract lettings; information about who submitted bids, and the nature of winning and losing bids, such as prices and compliance with district specifications, that were submitted to each district.

According to data obtained from the U.S. Department of Agriculture, a total of 68 milk processing plants had sales in Ohio at some point during the sample period and potentially could have supplied school milk. Figure 1 displays the location and owners of the 46 plants that supplied school milk in 1987. Superimposed on the plant location map in Figure 1 is an index of dairy concentration. ${ }^{12}$ The darker the area, the more concentrated is the ownership and control of local school milk processing facilities. Figure 1 shows that the markets in the northeast section of Ohio are the least concentrated, and if they were competitive they should have the lowest prices, all else equal. Columbus and the southernmost tip of Ohio have markets where the supply of school milk is concentrated in the hands of relatively few producers. Over the period 1980-1990, the number of plants serving Ohio school districts fell from 54 to 43 , and the number

\footnotetext{
${ }^{11}$ In some circumstances a reduced form model of bidding is behavioral, i.e., when each firm is 'small' relative to the market.

${ }_{12}$ We measure concentration using the Herfindahl index. For shares we use the fraction of plants within 75 miles of the region that are owned by each firm.
} 
of firms fell from 43 to 26.

Table 2 shows the distribution of bidder distances in the Ohio data. The table also shows the distribution of potential supplier distances in the data. Approximately 85 percent of the firms supplying school milk in a given year do so from plants located less than 75 miles from the school district. Firms considering entry in order to supply milk to distant school districts appear to be disadvantaged by distance, even if they have a plant in operation.

The distribution of processing plants in the state and the apparent disadvantage of shipping long distances cause districts to receive a relatively small number of bids on school milk. Table 3 shows the distribution of the number of bidders per district in the Ohio data. A majority of the auctions in the data set received bids from one or two bidders each year. Even though there are a large number of potential bidders for any particular auction, very few bid. The mean number of bids is 1.8 . Table 3 indicates that there may not be significant firm-specific private information in the markets. If bidders knew their own costs as well as the costs of other potential suppliers, then under a set of standard assumptions either one or two bids would be observed. Under these assumptions, the low cost supplier would submit a bid just below the cost of the next lowest cost supplier, and the next lowest cost supplier would be indifferent between bidding at their own cost or not bidding. Table 4 displays the characteristics of submitted and winning bids -- whether the firm is one of the closest potential suppliers, whether it is one of the second closest providers, or neither. About 43 percent of all bids are submitted by the firms with the plant closest to the district. The table also shows that almost half of all suppliers to school districts are the firms with the closest plants.

\section{A. Bid Submission}


In a competitive market a firm will submit a bid in a particular district whenever the probability of winning that district is relatively high, and when the expected return covers both the costs of preparing the bid and the incremental costs of supplying the district. ${ }^{13}$ A reduced form model of bidding behavior should account for variables that reflect the potential bidder's absolute and relative advantage in serving a district. For example, variables that may be important in characterizing these advantages include whether or not the firm (i) has significant transportation costs to the particular district, as reflected by the distance from the district to the plant; (ii) is a distributor or a processor of milk; (iii) is the closest potential supplier (and so the most likely low cost supplier for that district); (iv) is the second closest, and hence likely the second least costly potential provider; (v) is bidding on a large or small school district, as larger districts may require more time and energy to prepare a bid; and (vi) can efficiently provide the specified milk under the terms of the contract (e.g., whether or not coolers are required, whether firm or escalating contracts are specified, as well as other specifications).

From available bidding data, we estimate how these factors affect the decision of the control group to submit a bid. A list of the variables employed is contained in Table 5. Table 6 presents the results from the estimation of several Probit models, where the dependent variable is one if a bid is submitted in a district and the independent variables are as described in Table 5. The sample is an unbalanced panel of firms and district-years with available data. We present estimates based upon three different specifications. The first is a pooled specification with common intercepts and slopes across all districts and bidders. Column (a) displays the estimated

\footnotetext{
${ }^{13} \mathrm{~A}$ firm in the school milk business will make money if its bid price covers these costs and provides some contribution to fixed costs or overhead. As stated by a CEO of one of the defendant firms, the test is whether you are "better with or better without" the business.
} 
coefficients and (b) the estimated t-statistics. The second specification allows for separate bidder fixed effects. Column (c) displays the estimated coefficients from this specification and (d) the estimated t-statistics. The third specification allows for separate bidder and district effects estimated using a subsample of the data where these effects can be measured. District-specific dummies control for any effects that were specific to a school district and invariant over time or over firms submitting a bid. The distance coefficient is identified in the third specification because plant closures alter the distance between firms' closest plants and some districts. The contract specification coefficients may be less reliable, as they are often identified because information is missing for some years. Because of the large number of coefficients to be estimated (over 400) we break the problem into two pieces. ${ }^{14}$ The first set of results corresponds to the data from the first group of school districts. Column (e) displays the estimated coefficients and (f) the estimated t-statistics. Column (g) displays the estimated coefficients and (h) the estimated t-statistics from the second data subset. ${ }^{15}$ The coefficients of interest are similar across all three specifications.

We interpret the result as follows. Processors are more likely to submit bids than distributors, all else equal. This may reflect the fact that distributors tend to run a single school milk route, while processors tend to run several routes with school delivery. Firms are more likely to submit a bid in one particular direction as opposed to all around their plant, particularly distributors. This may reflect the effects of existing route structures. Firms are less likely to

\footnotetext{
${ }^{14}$ We order the data by district number and split the data so that each subset had about the same number of districts.

${ }^{15}$ Notice that a likelihood ratio test would probably reject the simpler models in favor of the more general model, suggesting that no single intercept can represent all bidders or all districts. That is, there is no bidder in the data that can be used to represent the bidding behavior of the others. The results should be interpreted in that light.
} 
submit bids on school districts that are further away from their plant than they are in closer districts. This probably reflects absolute cost differences. Districts that request coolers or straws receive fewer bids than districts that do not. The other specification items do not affect bidding behavior in a statistically significant way.

Distance has a negative effect on the likelihood of submitting a bid, except in the area where a firm has a locational advantage from having the closest plant. Figure 2 displays the impact of distance on the probability of bidding for a hypothetical firm in the control group. For this figure we assume that the firm is the closest supplier to districts less than 10 miles from its plant and the second closest potential supplier at distances between 10 and 20 miles. The three curves correspond to the different Probit specifications in Table 6. ${ }^{16}$ There are two steps in the predicted probability of bidding, where the firm loses its locational advantage and where it becomes neither the closest nor the second closest potential supplier. ${ }^{17}$ The likelihood of bidding for this hypothetical firm is above 50 percent at zero distance but decreases with distance. The estimated probability of submitting a bid is nearly zero at distances greater than 75 miles.

\section{B. Bid Level Contingent on Submission}

In competitive markets, a firm submitting a bid would choose its bid to maximize expected profit. A bid cannot be increased indefinitely; the higher the bid, the lower the likelihood of winning. To the extent that bids are costly to submit, it would not be profit maximizing to submit bids that have no probability of winning. An firm maximizing expected

\footnotetext{
${ }^{16}$ For the purposes of drawing the figure we average the estimated coefficients obtained from the district and firm fixed effects Probits based on the two subsets of the data.

${ }^{17}$ The steps occur because our Probit specifications employ indicator variables for these categories. However, the statistical procedure does not impose a restriction on the size or direction of the measured average effect.
} 
profit trades off higher profits against a lower probability of winning. ${ }^{18}$

Alternatively, bidders choose their markup over costs. The markup is affected by the likelihood of winning the auction, which depends on the likelihood of other firms submitting bids. The markup is chosen to maximize expected profit given the level of cost. There are two categories of variables that would tend to explain bidding behavior. First, there are variables that may contribute to cost, such as distance from the plant to the district; whether or not the bidder is a processor; whether or not coolers or other items are required or supplied; the number of required deliveries; and whether or not there is an escalator clause. Second, there are variables that reflect competitive characteristics of the market: the bidder's cost advantage relative to others and the competitive pressure in the market. For example, if a bidder is the closest vendor or has a plant that is closest to a school district, then that bidder has an advantage over others and its bid can be higher than it otherwise would be without decreasing its probability of winning. A second example is a variable that relates to the probability that a firm submits a bid. Firms that are likely to submit bids on particular districts are precisely those that have a high probability of winning, and those expecting to earn relatively high profits in the event that they win the auction.

To analyze bid prices we construct a summary measure of each firm's vector of bids, accounting for differences in butter fat content and flavoring. We predict the two percent chocolate price, in dollars per half pint, based upon each of the other prices submitted, in a pairwise manner. For example, in those instances where both a two percent chocolate and a white whole milk bid were entered, we regress the chocolate milk price on the white milk price and a constant. The estimated equation is used to forecast a two percent chocolate price based

\footnotetext{
${ }^{18}$ See e.g. Wilson (1993), McAfee and McMillan (1987), or Milgrom and Weber (1982).
} 
on the white whole milk price that was submitted. The average of the forecasts based on all observed component bids is used as the summary measure of price. The base is two percent chocolate. This procedure may introduce a form of heteroskedasticity into the model, and the statistical results should be interpreted accordingly. One alternative to our approach would be to estimate separate equations for each type of milk using a GLS procedure.

We measure the effects of the factors described above on the bid level decision for the control group as observed in the data set. Table 7 presents the results of the estimation procedures. Again, we present three sets of results. The first is based upon a simple Probit specification for bid submission and a corresponding OLS regression for bid levels, with correlation in the errors accounted for via a Heckit procedure. ${ }^{19}$ The second allows bidder specific constant terms in the Probit estimates and in the bid level equation. The third allows for both bidder and district specific fixed effects. District specific effects control for any variables that were specific to a school district and invariant over time or over firms submitting a bid. ${ }^{20}$ We interpret the results as follows. The greater the distance, the higher the bid. A bid 100 miles away would be over a penny higher than in a district adjacent to the plant, all else equal. Firms in the control group are unlikely to submit bids to districts at these distances from the plant, however. Distributors submit bids that are almost half a cent higher than those of processors. Firms closest to the district have some competitive advantage, but that advantage seems to diminish with distance. Firms that are likely to submit bids are more likely to bid low,

\footnotetext{
19 The statistical issues are described in Heckman (1976).

${ }^{20}$ These effects could include the number of schools in a school district; or any characteristics of the schools that remained constant over time, such as the number of flights of stairs to be negotiated, the condition of the roads within the school district, the traffic density in the area to the extent it was constant over time, and a variety of other possible factors.
} 
as reflected in the Inverse Mills Ratio coefficient. Some of the contract specifications are statistically significant. For example, when a firm submits an escalating bid as opposed to a fixed bid, the bid level is about 0.2 cents lower, all else equal, according to the bidder fixed effect model.

Figure 3 summarizes how control group bids vary with distance. We plot predicted bids for a hypothetical control group firm holding variables other than distance constant. The figure incorporates the effect of distance on the probability of submitting a bid and the resulting impact on the bid. We present the results for the three different specifications of the control group bidding model. In the district fixed effect model we adjust the constant so that the predicted line is comparable to the other models, which constrain the effects to be the same across all districts. ${ }^{21}$ Table 8 presents point estimates of the effect of distance on bids submitted for control group firms.

Bids by the control group increase with distance on average. The bidding data are consistent with competitive bidding under standard models of spatial competition, where each firm may exercise local monopoly power. As described above, competition is localized, because of the regulation of raw milk prices and because of relatively high transportation costs.

\section{BEHAVIOR OF DEFENDANTS}

\section{A. Comparison to Control Group Behavior}

We now examine the bidding practices of each of the defendant firms, and compare them with the control group. We consider both the bid submission decision and the level of the bid

\footnotetext{
${ }^{21}$ We select a district effect so that the predicted bid at zero distance is near the predicted bids at zero distance for the other specifications. One should not attribute any significance to the absolute difference between the lines plotted.
} 
contingent on submission.

Table 9 displays the results of a test of differences in bid submission behavior. We test for differences between the slope coefficients estimated for the control group and those estimated for each of the southwestern Ohio defendants. For each of the firms we use the following procedure: (1) append the submission data for a given defendant to the control group data; (2) estimate a model under the null hypothesis that the slope coefficients are the same for the firm and the control group firms (the intercept is allowed to differ); (3) estimate a model under the alternative hypothesis of separate slope coefficients for the defendant; and (4) construct a likelihood ratio test statistic. The test statistics reported in Table 9 lead us to reject the hypotheses that the defendants submitted bids according to the control group model at conventional significance levels. The test statistics were also computed for the specifications with bidder fixed effects and district and bidder fixed effects, and the tests lead to the same conclusion.

Next, we test for differences in the statistical process generating the level of bids. Table 10 displays the results of a LaGrange Multiplier test of equal slope coefficients in the bid level equations. $^{22}$ For each of the southwestern Ohio defendants we used the following procedure: (1) compute the predicted bid for the firm based on the control group bid equation estimates; (2) construct a residual (the difference between actual and predicted bids) for each school district and year when possible; (3) regress these residuals on the independent variables in the control group bid equation; and (4) compute an F-statistic to test whether all the slope coefficients equal zero. Under the null hypothesis of identical slope coefficients for the control group data and the

\footnotetext{
${ }^{22}$ The LM test was used for convenience. Of course, other test procedures (such as likelihood ratio) could have been used.
} 
defendants (the intercepts could differ, allowing a firm to have higher or lower bids, on average, under the null), the test statistic is unlikely to take extreme values. As Table 10 shows, each of the test statistics, except that of Beatrice, leads to a rejection of the null hypothesis at conventional significance levels. The test statistic computed for bids submitted under the Beatrice name (rather than the Meadow Gold name) does not lead to a rejection of the null hypothesis, but there are relatively few observations to base this statistic on, suggesting lower power for the test in this instance. There are many observations for this firm bidding under the Meadow Gold name, and there the null is rejected at conventional significance levels. The test statistic was computed for the other specifications considered, bidder fixed effects and district and bidder fixed effects, and we reach the same conclusions.

To summarize, standard statistical procedures indicate that the bidding behavior of each of the southwestern Ohio defendants differs from the control group. Behavioral differences are not necessarily the result of anti-competitive behavior. We are interested in how the behavior of each of the defendants differs from the control group, given that they differ.

\section{B. Comparison to a Collusive Strategy}

We are faced with a standard problem in antitrust economics: distinguishing between competitive and collusive behavior. ${ }^{23}$ In our previous work in highway construction auctions, we identify collusion by (1) focusing on bid levels rather than submission decisions, because conspirators apparently submitted complementary bids; (2) identifying differences in the determinants of the rank order of cartel bids relative to that of other firms; and (3) observing that the rank order of cartel bids seemed not to be cost based, in contrast to the rank order of bids

\footnotetext{
${ }^{23}$ Baker and Bresnahan (1992) discuss related methods of detecting the exercise of market power.
} 
submitted by other firms. Because these differences exist, we conclude that conspiracy is more likely than not. In a study of a nineteenth century railway cartel, Porter (1983) proposes statistical tests to identify whether competition or collusion is more consistent with observed data based on pricing patterns over time. Some observed price fluctuations do not appear to be the result of demand shifts or changes in observable cost factors. Instead, the observed pattern of occasional price wars, following periods of unusually turbulent market shares, is unlikely to be observed under competition. Under a specific theory of conspiracy, such a pattern is possible. The existence of a such a pattern informs an inference of collusion.

Our strategy for the problem at hand is similar. The non-defendant firms behave, on average, in a manner consistent with competition. We have concluded that the southwestern Ohio defendants behave in a statistically significantly different manner relative to the nondefendant firms. Is it likely that these differences are attributable to idiosyncratic effects of cost or competition? If not, are the differences attributable to independent factors, or are there suspicious patterns of correlation? We now address these two questions.

Since distance is an important factor in the control group model, we focus on that dimension. Moderate increases in shipping distance are associated with large declines in the probability of submitting a bid (Figure 2). Similarly, moderate increases in distance are associated with about ten percent increases in submitted bids in the control group (Figure 3). We examine the deviations of defendant firms' bidding behavior from the control group predictions in this context.

Table 11 presents a tabulation of differences between predicted and actual bid submission behavior for each of the southwestern Ohio defendants. The table displays the differences for 
several distance bands as a percent of the total number of school districts in each distance band. For example, column (c) in Table 11 indicates that Coors Brothers submitted 24.2 percent more bids in districts zero to ten miles from its plant than the control group data predict (after allowing for a firm specific effect). If 100 district/years fall in this band in the data, then about 24 more bids were observed than were predicted. In this case, a difference of 24.2 percent is statistically significant. ${ }^{24}$

There are some notable patterns in the table. First, Coors Brothers (column (c)), Meyer (d) and Louis Trauth (e) bid more frequently than the control group model predicts at distances of about 30 miles or less. Second, Meyer and Trauth bid more frequently at some of the greater distance intervals. Third, Beatrice/Meadow Gold (columns (a) and (f)) and Borden (b) bid less frequently than the model predicts at distances less than $\mathbf{4 0}$ miles. Finally, Borden and Meadow Gold bid more frequently at distances of about 70 to 100 miles.

Table 12 displays a similar tabulation for residuals based on the difference between the actual submitted bid ${ }^{25}$ and the control group prediction. The residuals are displayed as a percent of predicted bid. The average percent deviation for a particular distance category is calculated by regressing the residuals for each firm on a set of indicator variables for distance categories. The table displays the marginal effect of a particular distance category on the level of the bid. For example, Coors Brothers (column (c)) bids about 9.3 percent higher than predicted in districts that are zero to ten miles from their plant. The deviation between actual and predicted

\footnotetext{
${ }^{24}$ We compute the standard error of the fraction based on an approximation to a Bernoulli random variable. For the purposes of this calculation we ignore the fact that the predicted probability is a random variable with associated uncertainty.

${ }^{25}$ By actual bid, we are referring to the standardized bids rather than any element of the vector of bids that the firm may have submitted.
} 
bids that are submitted by Coors to districts ten to 20 miles away is about 0.7 percent higher than the deviation for the zero to ten category (i.e., about 10.0 percent above the control group). If the actual bidding of a particular firm was identical to control group bidding, except for a shift in the intercept, then the first row in Table 12 displays the size of the shift. Again, a shift in the bid function is not telling from a competitive point of view ${ }^{26}$, but each firm's bids (with the exception of Beatrice brand bids and Coors Brothers, which does not bid far from its plant) decrease relative to the control group prediction significantly with distance. For example, Borden bids (column (b)) are smaller than the control group bids by about five percent at a distance of 70 to 80 miles. Meyer, Trauth and Meadow Gold exhibit similar patterns.

In Table 13 we focus on whether firms behave in a parallel fashion. We test for statistical independence in the probability of bidding for the defendant firms using a standard procedure. ${ }^{27}$ In Table 13 we display the results of a test of pairwise independence of bid submission behavior. Under the null hypothesis of independent action based on public information and the maintained specifications of our Probit submission model, knowledge of whether one particular firm bids should not help predict whether another firm has also bid. Under an alternative hypothesis of either complementary bidding or territorial allocation, the submission decisions are interrelated, and knowing how one cartel member behaves helps predict what the other does. In the case of complementary bidding, if one cartel member bids, then other ring members also bid. In this case the unexplained portion of the competitive bidding equation is positively correlated across cartel firms. In the case of territorial allocation, if a particular cartel member bids then other cartel

\footnotetext{
${ }^{26}$ It is hard to explain why bids that are substantially above average can persist in a competitive market, however.

${ }^{27}$ See Greene (1993, pp. 661-663) or Kiefer (1982).
} 
members will tend not to bid. Then the unexplained portion of the competitive bidding equation is negatively correlated across cartel members. In Table 13 we display the Spearman correlation coefficients computed using pairs of weighted residuals based on the control group Probit models. The test for independence, or zero correlation, that we use has power against both alternatives. ${ }^{28}$ The results show that the unexplained portion of the Beatrice submission decision was positively correlated with the unexplained portion of the Meyer decision (and significant at any standard level). The significant results for the other pairs of firms are as follows: Borden with Meyer and Trauth; Coors with Meyer and Trauth; Meyer with all; and Trauth with Borden, Coors and Meyer. The Spearman correlation coefficients are large and positive for the Meyer, Trauth and Coors pairs.

We perform a similar analysis for residuals based on the level of the submitted bids. In Table 14 we display the Spearman correlation coefficient and the results of a test for pairwise independence of bidding behavior. ${ }^{29}$ Under the null hypothesis of independent action based on public information and the maintained specification of the bid level equations, knowledge of what one particular firm bid does not help predict what another firm will bid. Under an alternative hypothesis of complementary bidding, knowing that one cartel member bid above the predicted level helps predict whether other cartel firms will bid above that level. If one cartel member bids high, then other ring members are also likely to bid high. ${ }^{30}$ The results show, for example, that the unexplained portion of Beatrice's bid was statistically significantly correlated with Trauth's.

\footnotetext{
${ }^{28}$ The test statistic may also reject the null hypothesis of independent action if an important variable was omitted from the control group Probit model that affects these firms similarly.

${ }^{29}$ The test statistic is the Spearman correlation coefficient computed for the residuals based on the control group bidding model for each pair of defendants.

${ }^{30} \mathrm{This}$ test has little power to reject the null under an effective territorial allocation conspiracy, if there are no complementary bids, because we might not observe bids from ring members in the same district in the same year.
} 
The other significant results in the table indicate the following correlations: Borden with Meyer and Trauth; Coors with Meyer and Trauth; Meyer with Borden, Coors, Trauth and Meadow Gold; Trauth with all; and Meadow Gold with Meyer and Trauth. Sample sizes are largest for the three Meyer, Trauth and Coors pairs.

Our results support the testimony by representatives of Meyer and Coors. From Table 11 we observe that the behavior of Coors, Meyer and Trauth are consistent with a complementary bidding scheme in the area close to their plants, since more bids than expected are submitted at distances of less than 30 miles. From Table 12 we observe that these bids tend to be relatively high. The results in Tables 13 and 14 for these three firms are also consistent with a complementary bidding scheme. Table 13 shows statistically significant correlations in bid submissions by these firms, suggesting that if one of these firm bids then the others also tend to bid (to a greater extent than their proximity, size, and the like would predict). Table 14 reinforces these results since it also shows that when these firms bid on the same districts in the same years, their bids tend to move together (to a greater extent than their proximity, size, and the like would predict). It is difficult to craft a competitive story where bids decrease with distance, as they do for these firms. On the basis of our results, the collective behavior of these three firms is best characterized as collusive.

With respect to the other firms, Table 11 shows that Beatrice/Meadow Gold and Borden refrain from bidding in their local areas, where they would have a comparative advantage. Tables 13 and 14 provide evidence that bidding by Beatrice/Meadow Gold and Borden is correlated with Trauth bidding. This pattern is consistent with a complementary bidding scheme involving these firms. 


\section{EFfect OF Collusion on Prices PaId}

Assuming that a conspiracy involving all the southwestern Ohio defendants was in force throughout the 1980 's, what are the likely damages? Our methodology for estimating damages to the plaintiff school districts involves determining the percent markup in price attributable to collusion in various auctions.

We estimate using ordinary least squares the effect of variables that determine costs for the most efficient provider and other variables on the standardized price of the winning bid for district-year combinations in our sample. Table 15 describes the variables used in the analysis. The sample covers about 400 districts, including those outside of the Southwestern region. Annual dummy variables control for changes in the raw milk price, changes in uncertainties in the raw milk price over time, and changes in the costs of packaging year to year. We also control for district enrollment, the number of deliveries, and other characteristics of the school district. We include two relative location variables, which account for the effects of (1) the distance from the closest plant to the school district, as we expect price to be increasing with distance to the closest plant as shipping costs increase, and (2) the distance between the district and the second closest plant. When the latter distance is large, all else equal, we expect the price paid by the school district to be higher as the closest firm can charge a higher price.

We also control for the effects of differing levels of competition in each of the markets. We measured competition in these markets using the number of equivalent firms defined by the inverse of the Herfindahl index. ${ }^{31}$ We expect higher prices in more concentrated markets where

\footnotetext{
${ }^{31}$ The Herfindahl indices are based on the fraction of school milk processing plants within 75 miles of the district controlled by each processor. If there were ten owners of ten processing plants within 75 miles, then the Herfindahl is $1 / 10$ and our measure of competition is 10 . If there were ten dissimilar firms, the Herfindahl index will exceed $1 / 10$, and the number
} 
fewer firms compete with one another. Since there is no reason to expect a linear relationship between price and the competition index, we also include a quadratic term. We expect changes in the competition index to have a diminishing effect on price in competitive markets.

If there is collusion in these markets, prices are on average above the competitive level. Therefore, we include in each regression Delta, an index of collusion based on the number of conspirators in this case who are within 75 miles of the school district in question. ${ }^{32}$ There is also no reason to expect a linear relationship between the measure of the degree of collusion in these markets and price, so we include quadratic terms. We also include an interaction between the collusion index and the number of equivalent firms, since the effect of a restriction of competition will depend on the initial level of competition. We interact these indices of collusion with the annual dummy variables so as to measure, to the extent they exist, differences in the degree of collusion from year to year.

In Table 16 we display some of the estimated coefficients for the regression. The dependent variable is the logarithin of the winning standardized bid for two percent chocolate milk. In general, the coefficients are of the anticipated signs and statistically significant. The number of firms in the market, as measured by the two variables described above, indicate a significant effect of concentration on the price paid by the school districts.

In Table 17 we display the estimated regression coefficients for the variables related to collusion. We estimate separate coefficients for Delta and its interactions for each year. If the conspiracy was more effective in some years than in others, then the annual differences can be

\footnotetext{
of equivalent firms will be less than 10 .

${ }^{32}$ The index of collusion is the difference between the number of equivalent firms assuming competition and the number of equivalent firms assuming collusion.
} 
reflected. The predicted increase in price caused by collusion in these auctions is measured as the difference between the predicted value when indices of collusion are included and the predicted value that is obtained when all indices of collusion are set to zero. The difference is the predicted percentage change in standardized price resulting from collusion. Column (d) in Table 17 reports the estimated effect of collusion on the average district in southwestern Ohio by year. Column (e) in Table 17 reports the estimated effect of collusion on the average district in southwestern Ohio conditional on a defendant incumbency, by year. Note that the estimated effect of collusion is small in 1983-1984 and after 1989, according to both columns (d) and (e), consistent with the statements of market participants

The average effect of collusion on price is an increase of about six and one half percent. This is consistent with our estimate of the average effect of distance on school milk bids. If, for example, two nearby firms conspired to serve a district adjacent to their plants and faced competition only from firms located at least 50 miles from that school district, then prices could be about one half penny (or about five percent) higher than they otherwise would be. Districts further from potential competitors face higher markups and districts closer to the plants of competitive firms would pay lower markups. 


\section{REFERENCES}

Patrick Bajari, "A Structural Econometric Model of the First Price Sealed Bid Auction: With Applications to Procurement of Highway Improvements," University of Minnesota, mimeo, 1996.

Jonathan B. Baker and Timothy F. Bresnahan, "Empirical Methods of Identifying and Measuring Market Power," Antitrust Low Journal, Vol. 37 (1992), 3-16.

Laura H. Baldwin, Robert C. Marhsall and Jean-Francois Richard, "Bidder Collusion at Forest Service Timber Auctions," Pennsylvania State University, mimeo, 1995.

B. Douglas Bernheim and Michael D. Whinston, "Multimarket Contact and Collusive Behavior," Rand Journal of Economics, Vol. 21 (Spring 1990), 1-26.

William H. Greene, Econometric Analysis, Macmillan, New York, 1993.

James J. Heckman, "The Common Structure of Statistical Models of Truncation, Sample Selection and Limited Dependent Variables and a Simple Estimator for Such Models," Annals of Economic and Social Measurement, Vol. 5 (Fall 1976), 475-492.

Kenneth Hendricks and Robert H. Porter, "Collusion in Auctions," Annales d'Economie et de Statistique, No. 15/16 (July-December 1989), 217-230.

Diana Henriques and Dean Baquet, "Investigators Say Bid Rigging is Common in Milk Industry," New York Times, May 23, 1993.

Cynthia Hewitt, James McClave and David Sibley, "Incumbency and Bidding Behavior in the Dallas-Ft. Worth School Milk Market," University of Texas at Austin, mimeo, 1996.

Charles A. Holt and David T. Scheffiman, "Facilitating Practices: The Effects of Advance Notice 
and Best-Price Policies," Rand Journal of Economics, Vol. 18 (Summer 1987), 187-197.

Charles A. Holt and David T. Scheffman, "A Theory of Input Exchange Agreements," Federal Trade Commission, Bureau of Economics, mimeo, 1988.

Nicholas Kiefer, "Testing for Independence in Multivariate Probit Models," Biometrika, Vol. 69 (1982), 161-166.

R. Preston McAfee and John McMillan, "Auctions and Bidding," Journal of Economic Literature, Vol. XXV (June 1987), 699-738.

Paul R. Milgrom and Robert J. Weber, "A Theory of Auctions and Competitive Bidding," Econometrica, Vol . 50 (September 1982), 1089-1122.

Martin Pesendorfer, "A Study of Collusion in First Price Auctions," Yale University, mimeo, 1996.

Robert H. Porter, "A Study of Cartel Stability: The Joint Executive Committee," Bell Journal of Economics, Vol. 14 (Autumn 1983), 301-314.

Robert H. Porter and J. Douglas Zona, "Detection of Bid-Rigging in Procurement Auctions," Journal of Political Economy, Vol. 101 (June 1993), 518-538.

Robert Wilson, "Strategic Analysis of Auctions," in Handbook of Game Theory, Volume 1, ed. by R.J. Aumann and S. Hart, North Holland: Amsterdam, 1993, 227-279. 
Table 1 Characteristics of Ohio School Milk Data Set

\begin{tabular}{|c|c|c|c|c|c|c|}
\hline Year & $\begin{array}{c}\text { Number of } \\
\text { School } \\
\text { Districts or } \\
\text { Cooperatives }\end{array}$ & $\begin{array}{c}\text { Total } \\
\text { Enrollment } \\
\text { in School } \\
\text { Districts }\end{array}$ & $\begin{array}{l}\text { Number of } \\
\text { Plants } \\
\text { Operated by } \\
\text { Submitting } \\
\text { Dairies }\end{array}$ & $\begin{array}{c}\text { Number of } \\
\text { Dairies } \\
\text { Submitting } \\
\text { Bids } \\
\end{array}$ & $\begin{array}{c}\text { Average } \\
\text { Price per } \\
\text { Half Pint } \\
(\$ 0.00)\end{array}$ & $\begin{array}{c}\text { Average } \\
\text { FMO Price } \\
\text { for Raw } \\
\text { Milk(l }\end{array}$ \\
\hline 1980 & 366 & $1,257,925$ & 54 & 43 & 0.12823 & 0.0718 \\
\hline 1981 & 398 & $1,379,619$ & 50 & 44 & 0.12950 & 0.0769 \\
\hline 1982 & 415 & $1,371,164$ & 46 & 40 & 0.12954 & 0.0760 \\
\hline 1983 & 436 & $1,415,281$ & 48 & 40 & 0.12883 & 0.0764 \\
\hline 1984 & 448 & $1,430,644$ & 53 & 38 & 0.13133 & 0.0741 \\
\hline 1985 & 463 & $1,460,697$ & 48 & 35 & 0.13215 & 0.0708 \\
\hline 1986 & 481 & $1,457,437$ & 47 & 36 & 0.13042 & 0.0700 \\
\hline 1987 & 494 & $1,566,591$ & 46 & 33 & 0.13099 & 0.0701 \\
\hline 1988 & 509 & $1,520,635$ & 44 & 30 & 0.13378 & 0.0666 \\
\hline 1989 & 491 & $1,564,869$ & 43 & 26 & 0.13886 & 0.0708 \\
\hline 1990 & 412 & $1,296,587$ & 43 & 26 & 0.15751 & 0.0797 \\
\hline Notes: & $\begin{array}{l}\text { Dollars pe } \\
\text { Price quot }\end{array}$ & $\begin{array}{l}\text { ight FMO } \\
\text { f each yea }\end{array}$ & Class 1 Flui & $106 \mathrm{~h}$ & chuln & \\
\hline
\end{tabular}


Figure 11987 Regional Supply Concentration and Plant Locations

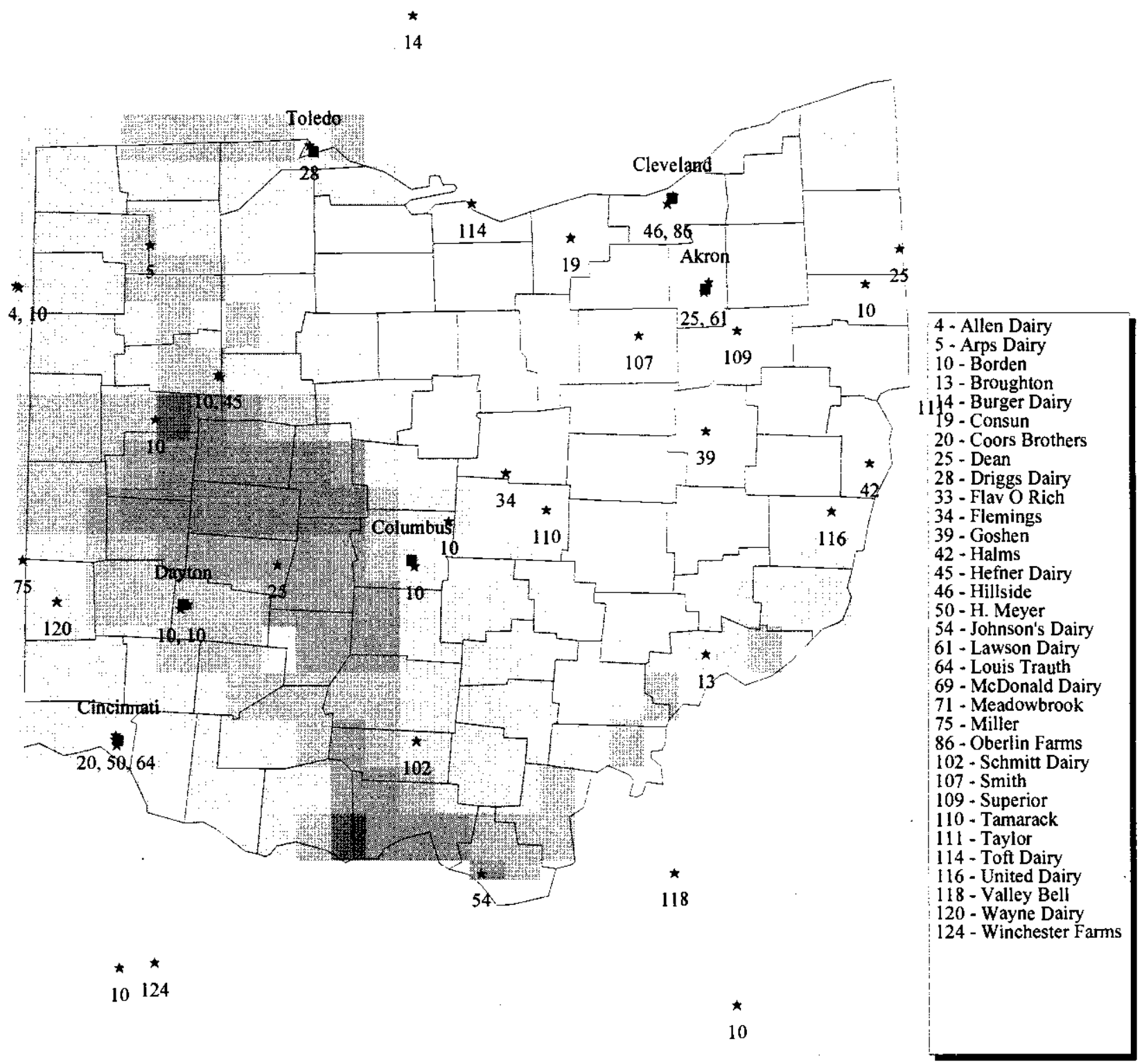

Note: The concentration of an area is represented by its shading; white represents a completely unconcentrated area while black represents an area serviced by a single supplier. 
Table 2 Probability of Bidding and Winning Conditional on Distance from Plant to School District, 1980-1990

\begin{tabular}{|c|c|c|c|c|c|}
\hline $\begin{array}{l}\text { Distance in } \\
\text { Miles }\end{array}$ & $\begin{array}{l}\text { Number of } \\
\text { Districts } \\
\text { (a) }\end{array}$ & $\begin{array}{l}\text { Probability of } \\
\text { Bidding } \\
\text { (b) }\end{array}$ & $\begin{array}{l}\text { Proportion of } \\
\text { All Bids } \\
\text { (c) }\end{array}$ & $\begin{array}{l}\text { Probability of } \\
\text { Winning } \\
\text { (d) }\end{array}$ & $\begin{array}{l}\text { Proportion } \\
\text { Winning Bi } \\
\text { (e) }\end{array}$ \\
\hline $0--10$ & 2115 & $19.5 \%$ & $20.1 \%$ & $13.6 \%$ & $22.9 \%$ \\
\hline $10-20$ & 3197 & 14.0 & 21.7 & 8.9 & 22.5 \\
\hline $20-30$ & 3840 & 7.6 & 14.2 & 4.9 & 15.0 \\
\hline $30-40$ & 4526 & 5.5 & 12.1 & 3.4 & 12.1 \\
\hline $40-50$ & 5637 & 2.3 & 6.3 & 0.9 & 4.2 \\
\hline $50-60$ & 6440 & 1.9 & 5.9 & 1.0 & 5.0 \\
\hline $60-70$ & 5314 & 1.4 & 3.7 & 0.5 & 2.0 \\
\hline $70-80$ & 6732 & 1.4 & 4.7 & 0.8 & 4.4 \\
\hline $80-90$ & 5200 & 1.0 & 2.5 & 0.6 & 2.5 \\
\hline $90--100$ & 4885 & 1.2 & 2.8 & 0.7 & 2.8 \\
\hline $100-150$ & 26079 & 0.5 & 6.1 & 0.3 & 6.6 \\
\hline
\end{tabular}

Notes: Columns (b) and (d) report, for each distance category, the percentage of districts in which firms submitted a bid or the winning bid, respectively. Columns (c) and (e) total 100 percent and report the fraction of all bids or winning bids, respectively in each distance category. Results are based on a total of 2053 submitted bids from control group firms out of 73965 bid opportunities, 1260 of these were winning bids. 
Table 3 Distribution of Number of Bidders per Auction 1980-1990, All Firms

$\begin{array}{crr}\text { Number of Bidders } & \begin{array}{c}\text { Number of } \\ \text { Auctions }\end{array} & \begin{array}{c}\text { Sample } \\ \text { Proportion }\end{array} \\ \text { One } & 1739 & 45.0 \% \\ \text { Two } & 1300 & 33.6 \% \\ \text { Three } & 702 & 18.2 \% \\ \text { Four } & 106 & 2.7 \% \\ \text { Five } & 18 & 0.5 \% \\ \text { Six } & 1 & 0.0 \% \\ \text { Total } & 3866 & 100.0 \%\end{array}$

Notes: Calculations are based on data from all firms, control group and defendant firms. 


\section{Table 4 Distribution of Bids and Wins by Relative Distance}

\begin{tabular}{lcccc}
\multicolumn{3}{c}{ Relative Proximity } \\
& Closest & Second Closest & Other & Sample Size \\
Submitted Bids & $42.8 \%$ & $7.8 \%$ & $49.4 \%$ & 6965 \\
Winning Bids & $48.8 \%$ & $8.3 \%$ & $42.9 \%$ & 3511
\end{tabular}

Notes: Column (a) reports the percentage of submitted and winning bids, respectively, accounted for by the firms with the plant closest to the school district. Column (b) reports similar numbers for the firms with the plants second closest to the school district. Calculations are based on data from all firms. 


\section{Table $5 \quad$ Variable Definitions}

\section{Continuous Variables}

Direction Proportion of the vendor's bids from 1980-1990 thats were submitted in the quadrant in which the district is located relative to the plant.

Distance Approximate distance (in miles) between district and plant.

Size Share of Ohio students represented in the data set served by the vendor in the given year,

District Enrollment Number of students enrolled in the district in the 1993-1994 school year.

Inverse Mills Ratio Inverse of the Mills Ratio, which is a function of the probability of submitting a bid.

Number Deliveries When available, number of deliveries per week (otherwise, Number Deliveries is zero and Delivery Missing is one).

Student Spread Variance of enrollment across districts belonging to a co-op or other auction-conducting entity. This measure equals zero for districts that do not belong to a co-op or other auction-conducting entity.

District Spread Mean distance (in miles) between each district and the auction-conducting entity. This measure equals zero for districts that do not belong to a co-op or other auction-conducting entity.

\section{Indicator Variables}

Processor One if the vendor is a processor, zero otherwise.

Closest One if the plant is the closest to the district, zero otherwise.

Second Closest One if the plant is the second closest to the district, zero otherwise.

No Cooler One if information on coolers available and no cooler supplied, zero otherwise.

Cooler Provided One if information on coolers available and cooler supplied, zero otherwise.

Fixed Bid One if information on escalator clauses available and bid is fixed, zero otherwise.

Escalator One if information on escalator clauses available and bid is not fixed, zero otherwise

Straws Not Included One if information on straws available and no straws supplied, zero otherwise.

Straws Included $\quad$ One if information on straws available and straws supplied, zero otherwise.

Delivery Missing One if no information available on deliveries per week, zero otherwise.

Coop One if an entity is holding the auction on behalf of multiple school districts, zero otherwise.

$1981-1990$ One if bid was made in the indicated year, zero otherwise.

\section{Interaction Terms}

Direction* Distance Processor*Direction Processor*Distance Size* Distance Closest* Distance Coop*Student Spread
Processor* Direction*Distance

(Size* Distance) $)^{\wedge}$

Coop*District Spread 


\begin{tabular}{|c|c|c|c|c|c|c|c|c|}
\hline \multirow[b]{2}{*}{ Variable Name } & \multicolumn{2}{|c|}{$\begin{array}{c}\text { Base Probit } \\
\text { Submission Model }\end{array}$} & \multicolumn{2}{|c|}{$\begin{array}{c}\text { Bidder } \\
\text { Fixed Effect } \\
\text { Submission Model }\end{array}$} & \multicolumn{4}{|c|}{$\begin{array}{l}\text { District and Bidder } \\
\text { Fixed Effect } \\
\text { Submission Model }\end{array}$} \\
\hline & Coefficient & t-stat & Coefficient & t-stat & Coefficient & t-stat & Coefficient & t-stat \\
\hline Constant & -2.559938 & -23.3 & $\mathrm{NA}$ & & NA & & NA & \\
\hline Direction & 1.146110 & 16.1 & 1.272590 & 15.5 & 1.327270 & 8.2 & 1.402290 & 8.7 \\
\hline Direction*Distance & 0.005570 & 3.6 & 0.013020 & 70 & 0.034980 & 9.4 & 0.020440 & 5.3 \\
\hline Processor*Distance & -0.035257 & -15.4 & .0 .047488 & -13.2 & -0.033911 & -5.9 & -0.081996 & $\cdot 10.3$ \\
\hline Distance & -0.015453 & -10.1 & -0.022971 & -12.4 & -0.046533 & -12.7 & -0.038826 & -9.7 \\
\hline Processor & 1.778220 & 18.6 & 1.689650 & 10.4 & 1.276780 & 4.8 & 1.904400 & 5.3 \\
\hline Size & 27.876500 & 17.0 & 12.202800 & 4.6 & 22.600400 & 5.0 & 14.189400 & 2.6 \\
\hline Size*Distance & 0.166440 & 3.2 & 0.122250 & 2.1 & 0.049420 & 0.4 & 0.086190 & 0.8 \\
\hline$\left(\text { Size }^{*} \text { Distance }\right)^{\wedge} 2$ & -0.033525 & -4.5 & -0.000835 & -0.1 & .0 .000078 & -0.0 & 0.005240 & 0.4 \\
\hline Cooler Provided & 0.092010 & 2.9 & 0.082250 & 2.3 & 0.070520 & 0.7 & 0.166430 & 1.5 \\
\hline Fixed Bid & -0.053259 & -1.2 & 0.015580 & 0.3 & -0.007408 & -0.1 & 0.029990 & 0.2 \\
\hline Escalator & -0.091004 & .1 .6 & -0.033242 & -0.5 & 0.353040 & 2.3 & -0.436068 & -2.0 \\
\hline Straws Not Included & .0 .095246 & -0.9 & .0 .134499 & -1.2 & .0 .053058 & -0.1 & 0.462130 & 1.6 \\
\hline Straws Included & -0.081417 & -2.0 & .0 .100796 & -2.2 & -0.197628 & -1.5 & -0.236998 & -1.4 \\
\hline Delivery Missing & 0.288980 & 3.4 & 0.273640 & 2.9 & 0.118890 & 0.4 & -0.352962 & $\cdot 1.0$ \\
\hline Number Deliveries & 0.066800 & 3.2 & 0.065210 & 2.8 & 0.038060 & 0.5 & -0.098841 & -1.2 \\
\hline Cooperative & -0.031756 & -0.3 & -0.009502 & .0 .1 & NA & & -73.672650 & -0.5 \\
\hline Geographic Spread & 0.000560 & 0.6 & 0,000100 & 0.1 & NA & & 0.141030 & 0.5 \\
\hline Variance of Population & 0.000000 & 1.9 & 0,000000 & 1.8 & NA & & $.0,000000$ & -0.0 \\
\hline Observations: & & 73965 & & 73965 & & 27296 & & 21110 \\
\hline Number of Parameters: & & 25 & & 89 & & 271 & & 265 \\
\hline
\end{tabular}


Figure 2 Predicted Probability of Submitting a Bid by Distance

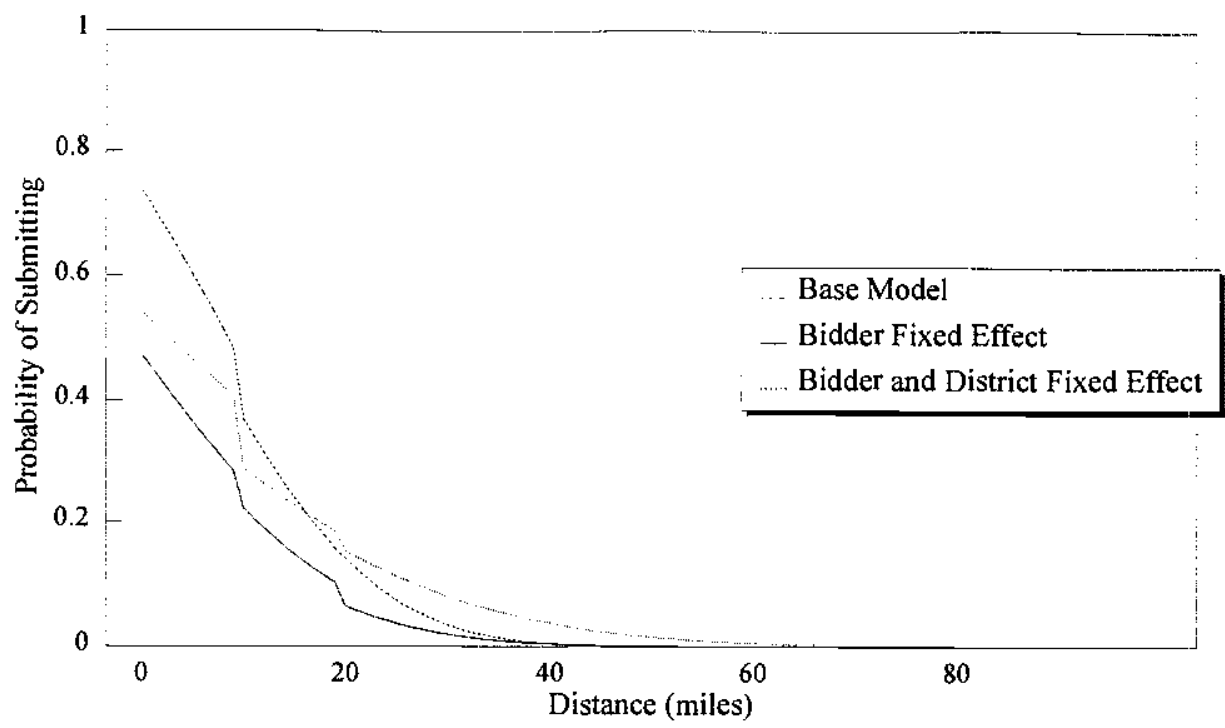

Note:

Variables that are not related to distance are set to their mean value, except processor is set to one, closest is set to one at distances less than 10 miles and closer is set to one at distances between 10 and 20 miles 
Table 7 Estimated Coefficients: Control Group Bid Level

\begin{tabular}{|c|c|c|c|c|c|c|}
\hline \multirow{3}{*}{ Variable Name } & \multicolumn{2}{|c|}{ Bid Model } & \multicolumn{2}{|c|}{$\begin{array}{c}\text { Bidder } \\
\text { Fixed Effect } \\
\text { Bid Model }\end{array}$} & \multicolumn{2}{|c|}{$\begin{array}{l}\text { District and Bidder } \\
\text { Fixed Effect } \\
\text { Bid Model }\end{array}$} \\
\hline & Coefficient & t-stat & Coefficient & t-stat & Coefficient & t-stat \\
\hline & & & & & & \\
\hline Constant & 0.123542 & 59.5 & 0.128517 & 33.9 & 0.122851 & 0.0 \\
\hline Processor*Distance & 0.000009 & 0.6 & 0.000065 & 2.9 & 0.000070 & 2.5 \\
\hline Distance & 0.000027 & 2.3 & 0.000004 & 0.3 & -0.000026 & -1.4 \\
\hline Processor & -0.002200 & -3.1 & -0.001300 & -0.7 & -0.003972 & -1.9 \\
\hline Closest & 0.003535 & 4.1 & 0.000494 & 0.6 & 0.000960 & 0.8 \\
\hline Closest*Distance & -0.000069 & -2.3 & -0.000002 & -0.1 & 0.000005 & 0.1 \\
\hline District Enrollment & -0.000000 & -3.2 & -0.000000 & -1.3 & 0.000000 & 0.0 \\
\hline Inverse Mills Ratio & 0.001713 & 2.9 & 0.001586 & 2.6 & 0.002115 & 3.5 \\
\hline No Cooler & 0.002324 & 2.4 & -0.000390 & -0.5 & -0.000193 & -0.1 \\
\hline Cooler Provided & 0.000802 & 1.5 & 0.001320 & 3.2 & 0.000627 & 1.0 \\
\hline Fixed Bid & 0.002334 & 3.1 & 0.001174 & 2.0 & -0.001181 & -1.3 \\
\hline Escalator & -0.003030 & -3.5 & -0.000890 & -1.3 & 0.000931 & 0.8 \\
\hline Straws Not Included & -0.000370 & -0.2 & 0.000389 & 0.3 & 0.003169 & 1.6 \\
\hline Straws Included & -0.001630 & -2.4 & -0.001120 & -2.1 & -0.000612 & -0.7 \\
\hline Delivery Missing & 0.001683 & 1.1 & -0.001000 & -0.9 & 0.000564 & 0.3 \\
\hline Number Deliveries & 0.000457 & 1.3 & -0.000450 & -1.6 & -0.000061 & -0.1 \\
\hline Cooperative & 0.001291 & 0.7 & 0.000341 & 0.2 & NA & NA \\
\hline Geographic Spread & -0.000009 & -0.5 & -0.000012 & -0.9 & -0.003515 & -1.9 \\
\hline Variance of Population & -0.000000 & -0.5 & -0.000000 & -3.2 & 0.000000 & 0.0 \\
\hline 1981 & 0.001551 & 1.6 & 0.003177 & 4.4 & 0.003004 & 4.4 \\
\hline 1982 & 0.000077 & 0.1 & 0.000329 & 0.4 & 0.000213 & 0.3 \\
\hline 1983 & 0.000035 & 0.0 & 0.000657 & 0.9 & 0.000644 & 0.9 \\
\hline 1984 & 0.002531 & 2.6 & 0.002080 & 2.5 & 0.001957 & 2.5 \\
\hline 1985 & 0.002998 & 2.9 & 0.002679 & 3.1 & 0.002722 & 3.4 \\
\hline 1986 & 0.000868 & 0.9 & 0.001365 & 1.6 & 0.001382 & 1.7 \\
\hline 1987 & 0.001101 & 1.1 & 0.001594 & 1.9 & 0.001765 & 2.2 \\
\hline 1988 & 0.003967 & 4.0 & 0.004539 & 5.3 & 0.004941 & 6.0 \\
\hline 1989 & 0.010246 & 10.3 & 0.011488 & 13.2 & 0.011598 & 13.8 \\
\hline 1990 & 0.031683 & 31.0 & 0.032510 & 36.1 & 0.033565 & 37.5 \\
\hline Bidder Specific Effects & No & & Yes & & Yes & \\
\hline District Specific Effects & No & & No & & Yes & \\
\hline R-square & 0.4891 & & 0.7337 & & 0.8347 & \\
\hline RMSE & 0.009540 & & 0.007000 & & 0.006144 & \\
\hline Observations & 2053 & & 2053 & & 2053 & \\
\hline Degrees of Freedom & 2024 & & 1959 & & 1580 & \\
\hline
\end{tabular}

Notes: Inverse Mills Ratios were computed using the appropriate probit coefficeints -i.e. the base regression model uses the base probit coefficient 
Figure 3 Predicted Level of Submitted Bids by Distance: Control Group

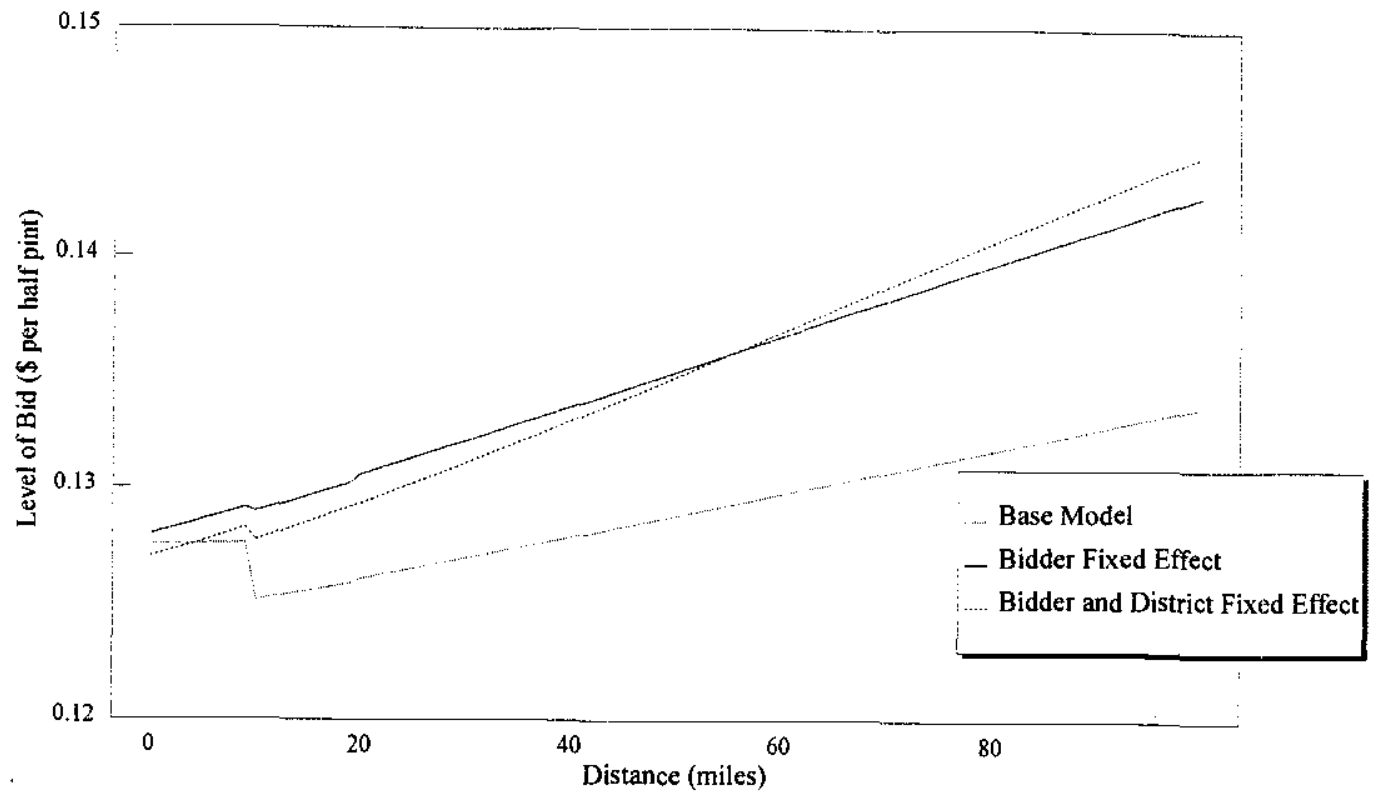

Note: Variables that are not related to distance are set to their mean value, except processor is set to one, closest is set to one at distances less than 10 miles and closer is set to one at distances between 10 and 20 miles 


\section{Table 8 Estimated Effect of Distance on Submitted Bids Control Group Firms}

$\begin{array}{lcc} & \begin{array}{c}\text { Estimated } \\ \text { Effect Where } \\ \text { Closest }\end{array} & \begin{array}{c}\text { Estimated } \\ \text { Effect Where } \\ \text { Not Closest }\end{array} \\ \text { Base Model } & 0.00077244 & 0.00960348 \\ \text { Bidder Fixed Effects } & 0.01160613 & 0.01535559 \\ \text { Bidder/District Fixed Effects } & 0.01249768 & 0.01941482\end{array}$

Note: $\quad$ Estimated effect is measured in dollars per half pint per hundred miles of distance. For example, a figure of 0.01 indicates that bids would be one penny higher one hundred miles away, all else being equal. The estimated models were used with variables that are not related to distance are set to their mean value, except processor is set to one. Estimated effects represent the derivative of the bid equation with respect to distance. 
Table 9 Test of Equality of Coefficeints from Control Goup Probit Estimates and Southwestern Ohio Defendants

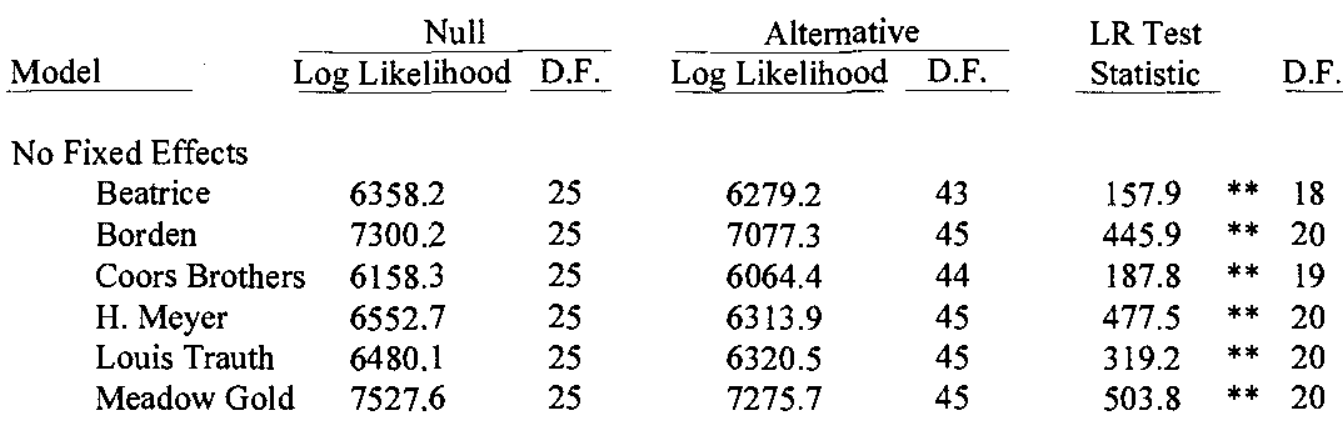

Note: Two stars indicate statistical significance at the one percent level. We report test results for the base models.

The null hypothesis is that slope coefficients are the same for the pooled control group and the defendant, the alternative hypothesis is that they are not. 


\section{Table 10 Statistical Deviations from Control Group OLS Estimates Southwestern Ohio Defendents}

\begin{tabular}{|c|c|c|c|c|c|}
\hline \multirow[b]{2}{*}{ Model } & \multicolumn{2}{|c|}{ Degrees of Freedom } & \multirow[b]{2}{*}{ F-Stat } & \multirow{2}{*}{\multicolumn{2}{|c|}{$\begin{array}{l}\text { Sig. } \\
\text { Level }\end{array}$}} \\
\hline & Num & Denom & & & \\
\hline \multicolumn{6}{|l|}{ No Fixed Effects } \\
\hline Beatrice & 19 & 78 & 1.09 & 0.3774 & \\
\hline Borden & 26 & 386 & 10.13 & 0.0000 & $* *$ \\
\hline Coors Brothers & 25 & 102 & 5.02 & 0.0000 & $* *$ \\
\hline H. Meyer & 26 & 384 & 11.53 & 0.0000 & $* *$ \\
\hline Louis Trauth & 25 & 345 & 9.66 & 0.0000 & $* *$ \\
\hline Meadow Gold & 25 & 771 & 7.09 & 0.0000 & $* *$ \\
\hline
\end{tabular}

Note: Two stars indicate statistical significance at the one percent level. We report test results for the base models.

We have regressed residuals for each firm based on control group coefficients on the independent variables and a constant. The reported F-statistic is for the joint test of whether the slopes are zero. 
Distance in Miles

$$
\begin{array}{r}
0-10 \\
10-20 \\
20-30 \\
30-40 \\
40--50 \\
50-60 \\
60--70 \\
70--80 \\
80--90 \\
90--100 \\
100-110 \\
110--120 \\
120--130 \\
130--140 \\
140--150
\end{array}
$$

\author{
Beatrice
}

(a)

$$
\begin{aligned}
& -13.7 \%< \\
& -9.8 \%< \\
& 6.9 \%> \\
& 0.5 \% \\
& 3.1 \%> \\
& -0.7 \% \\
& 0.4 \% \\
& 3.3 \%> \\
& -0.3 \% \\
& -0.5 \% \\
& -0.0 \% \\
& -0.0 \% \\
& -0.0 \% \\
& -0.0 \% \\
& -0.0 \%
\end{aligned}
$$

$$
\text { Borden }
$$$$
\text { (b) }
$$

$$
\text { Coors }
$$$$
\text { Brothers }
$$

Meyer

(d)

Louis

Trauth

(e)
Meadow Gold
(f)

$-0.2 \%$
$-2.2 \%$
$-9.3 \%<$
$-11.1 \%<$
$-1.3 \%$
$-2.5 \%<$
$-1.9 \%<$
$2.4 \%>$
$11.8 \%>$
$8.2 \%>$
$7.5 \%>$
$-0.5 \%$
$0.6 \%$
$-0.0 \%$
$-0.0 \%$

$5.6 \%>$
$8.2 \%$
$18.5 \%>$
$18.6 \%>$
$-2.2 \%$
$-5.5 \%$
$-18.6 \%<$
$-25.0 \%<$
$-17.5 \%<$
$-7.7 \%<$
$30.7 \%>$
$0.5 \%$
$-0.9 \%$
$-0.3 \%$
$-0.1 \%$

$7.0 \%>$ $15.2 \%>$

$20.6 \%>$ $0.1 \%$

$-4.3 \%$

$6.9 \%$

$47.1 \%>$

$10.0 \%>$

$-2.5 \%<$

$-11.8 \%<$

$8.7 \%>$

$-4.2 \%<$

$-3.6 \%<$

$-2.0 \%$

$-1.2 \%$

$A^{\prime}<{ }^{\prime}('>)$ indicates that actual bidding is statistically significantly below (above) the predicted level, at a 95 percent confidence level.

The standard error of each prediction is computed using $p^{*}(1-p)$ approximation to the variance of a Bernoulli random variable. The probit model incorporating no fixed effects (the base model) is used for these calculations. 


\section{Table 12 Percent Deviations in Predicted and Actual Bid by Distance: Southwestern Ohio Defendents}

\begin{tabular}{|c|c|c|c|c|c|c|}
\hline $\begin{array}{c}\text { Distance in } \\
\text { Miles }\end{array}$ & Beatrice & Borden & $\begin{array}{l}\text { Coors } \\
\text { Brothers }\end{array}$ & Meyer & $\begin{array}{l}\text { Louis } \\
\text { Trauth }\end{array}$ & $\begin{array}{c}\text { Meadow } \\
\text { Gold }\end{array}$ \\
\hline & (a) & (b) & (c) & (d) & (e) & (f) \\
\hline $0-10$ & $-4.9 \%<$ & $1.9 \%>$ & $9.3 \%>$ & $2.7 \%>$ & $5.5 \%>$ & $0.1 \%$ \\
\hline $10-20$ & $2.6 \%$ & $1.7 \%>$ & $0.7 \%$ & $-1.8 \%$ & $-0.4 \%$ & $-1.1 \%$ \\
\hline $20-30$ & $-0.6 \%$ & $-0.6 \%$ & $2.3 \%$ & $1.3 \%$ & $-2.2 \%$ & $0.9 \%$ \\
\hline $30-40$ & $-1.3 \%$ & $-0.3 \%$ & $-3.0 \%$ & $2.5 \%$ & $-1.1 \%$ & $0.6 \%$ \\
\hline $40--50$ & $1.5 \%$ & $-0.3 \%$ & $5.8 \%$ & $-5.6 \%<$ & $2.1 \%$ & $0.1 \%$ \\
\hline $50--60$ & $6.3 \%$ & $-1.8 \%$ & & $1.4 \%$ & $-2.3 \%$ & $-1.5 \%$ \\
\hline $60-70$ & $.2 .9 \%$ & $1.7 \%$ & & $-1.0 \%$ & $-6.1 \%<$ & $0.4 \%$ \\
\hline $70--80$ & $-0.5 \%$ & $-5.1 \%<$ & & $-2.7 \%$ & $0.6 \%$ & $3.0 \%$ \\
\hline $80--90$ & & $0.6 \%$ & & $-3.7 \%$ & $2.9 \%$ & $-7.2 \%<$ \\
\hline $90--100$ & & $-2.1 \%$ & & $12.8 \%$ & $5.8 \%$ & $2.7 \%$ \\
\hline $100--110$ & & $3.4 \%$ & & $-11.6 \%<$ & $-8.9 \%$ & \\
\hline $110-120$ & & $-2.5 \%$ & & $3.7 \%$ & $-2.4 \%$ & \\
\hline $120-130$ & & & & & & \\
\hline $130-140$ & & & & & & \\
\hline $140-150$ & & & & & & \\
\hline
\end{tabular}

at a 95 percent confidence level.

Estimates are obtained by regressing residuals based on control group model on distance category dummy variables. Models incorporating no fixed effects are used for these calculations 


\section{Table 13 Correlations Among Paired Probit Residuals: Southwestern Ohio Defendents}

Firm

Beatrice

Borden

Coors Brothers

H. Meyer

Louis Trauth

\begin{tabular}{|c|c|c|c|c|}
\hline Borden & $\begin{array}{l}\text { Coors } \\
\text { Brothers }\end{array}$ & H. Meyer & $\begin{array}{l}\text { Louis } \\
\text { Trauth }\end{array}$ & $\begin{array}{l}\text { Meadow } \\
\text { Gold }\end{array}$ \\
\hline $\begin{array}{r}0.0967 \\
1609\end{array}$ & $\begin{array}{r}0.0491 \\
761\end{array}$ & $\begin{array}{c}0.0522 * * \\
896\end{array}$ & $\begin{array}{r}0.0627 \\
791\end{array}$ & $\begin{array}{c}-0.03433^{* *} \\
1609\end{array}$ \\
\hline & $\begin{array}{r}0.1952 \\
1379\end{array}$ & $\begin{array}{c}0.2129 \\
1522\end{array}$ & $\begin{array}{c}0.2020 * * \\
1410\end{array}$ & $\begin{array}{c}0.09477^{*} \\
2158\end{array}$ \\
\hline & & $\begin{array}{c}0.5813^{* *} \\
1432\end{array}$ & $\begin{array}{c}0.4344^{* *} \\
1320\end{array}$ & $\begin{array}{r}0.2059 \\
1193\end{array}$ \\
\hline & & & $\begin{array}{c}0.5389 * * \\
1463\end{array}$ & $\begin{array}{c}0.1188^{* *} \\
1328\end{array}$ \\
\hline & & & & $\begin{array}{c}0.1124^{*} \\
1223\end{array}$ \\
\hline
\end{tabular}

The number of observations used in the calculations are displayed below the correlations. Two stars indicated statistical significance at the one percent level. One star indicates significance at the ten percent level. The test statistic used is an LM statistic for independence of binary probits derived by Kiefer (1982). 
Table 14 Correlations Among Paired Bid-Level Residuals: Southwestern Ohio Defendents

\begin{tabular}{|c|c|c|c|c|c|}
\hline Firm & Borden & $\begin{array}{l}\text { Coors } \\
\text { Brothers }\end{array}$ & H. Meyer & $\begin{array}{l}\text { Louis } \\
\text { Trauth }\end{array}$ & $\begin{array}{c}\text { Meadow } \\
\text { Gold }\end{array}$ \\
\hline \multirow[t]{2}{*}{ Beatrice } & -0.3571 & -1.0000 & 0.0091 & 0.9182 & NA \\
\hline & 8 & 3 & 11 & 11 & 0 \\
\hline \multirow[t]{2}{*}{ Borden } & & -0.2571 & $0.2743 *$ & 0.3724 & 0.1634 \\
\hline & & 6 & 73 & 51 & 59 \\
\hline \multirow{2}{*}{\multicolumn{2}{|c|}{ Coors Brothers }} & & $0.6598 * *$ & 0.5366 & -1.0000 \\
\hline & & & 126 & 114 & 2 \\
\hline H. Meyer & & & & $\begin{array}{r}0.6674 \\
267\end{array}$ & $\begin{array}{c}0.3539^{* *} \\
69\end{array}$ \\
\hline Louis Trauth & & & & & $\begin{array}{c}0.6317^{* *} \\
58\end{array}$ \\
\hline
\end{tabular}

Note: Spearman correlation coefficient among OLS residuals from base model.

The number of observations used in the calculations are displayed below the correlations. Two stars indicated statistical significance at the one percent level. One star indicates significance at the ten percent level.

The null hypothesis is no correlation in residuals, the alternative is that the residuals are correlated. 


\section{Table 15 Variable Definitions}

\section{Dependent Variable}

Log of Standard Bid The natural logarithm of the standardized bid of the winner of the district.

\section{Independent Variables}

Equivalent Firms The equivalent number of equal sized firms assuming competition, based on the Herfindhal Index described in the text.

Equivalent Firms $s^{\wedge} \quad$ The square of Equivalent Firms

Delta The difference between the equivalent number of equal sized firms assuming competition and the equivalent number of equal sized firms assuming collusion.

Delta^2 The square of Delta

Closest Approximate distance (in miles) between the district and the closest plant.

Second Closest Approximate distance (in miles) between the district and the second closest plant.

Log of District Enrollment The natural logarithm of the nuber of students enrolled in the district in the 1993-1994 school year

Number Deliveries When available, number of deliveries per week (otherwise Number Deliveries is zero and Delivery Missing is one).

\section{Indicator Variables}

No Cooler

One if information on coolers available and no cooler supplied, zzro otherwise.

Cooler Provided

One if information on coolers available and cooler supplied, zero otherwise.

Fixed Bid

One if information on escalator clauses available and bid is fixed, zero otherwise.

Escalator

One if information on escalator clauses available and bid is not fixed, zero otherwise.

Straws Not Included

One if information on straws available and no straws supplied, zero otherwise.

Straws Included

One if information on straws available and straws supplied, zero otherwise.

Delivery Missing

One if no information available on deliveries per week, zero otherwise.

Region

One if the district is in the western part of Ohio, zero otherwise.

$1981-1990$

One if bid was made in the indicated year, zero otherwise.

\section{Interaction Terms}

All other variables are the product of variables defined above. 


\section{Estimated Competitive Market Price Equation}

\begin{tabular}{lrr}
\multicolumn{1}{c}{ Variable } & $\begin{array}{c}\text { Estimated } \\
\text { Coefficient }\end{array}$ & t-Statistic \\
\cline { 2 - 3 } Constant & & \\
Equivalent Firms & -1.7794 & -96.1 \\
Equivalent Firms 2 & -0.0150 & -5.7 \\
Closest & -0.0003 & -1.3 \\
Second Closest & -0.0004 & -3.6 \\
Log of District Enrollment & 0.0003 & -0.0134 \\
No Cooler & 0.0041 & -11.9 \\
Cooler Provided & 0.0076 & 0.9 \\
Fixed Bid & -0.0024 & -0.8 \\
Escalator & -0.0096 & -4.2 \\
Straws Not Included & -0.0020 & -0.6 \\
Straws Included & 0.0033 & 1.2 \\
Number Deliveries & 0.0007 & 0.3 \\
Delivery Missing & -0.0009 & -0.1 \\
1981 & -0.0303 & -2.4 \\
1982 & -0.0572 & -4.5 \\
1983 & -0.0744 & -5.9 \\
1984 & -0.0814 & -6.4 \\
1985 & -0.0593 & -4.7 \\
1986 & -0.0987 & -7.8 \\
1987 & -0.1118 & -8.8 \\
1988 & -0.0927 & -7.4 \\
1989 & -0.0367 & -2.9 \\
1990 & 0.0992 & 7.6 \\
& & \\
R-Square & 0.6239 & \\
Number of Observations & 3431 &
\end{tabular}

Note: Model is estimated using data from all districts. The model controls for the effects of collusion by including the variable Delta and related variables. The estimated effect of collusion is presented on the next table. 


\section{Table 17 Estimated Effect of Collusion on the Price Paid by School Districts: Southwestern Ohio}

$\begin{array}{cccccc}\text { Year } & \begin{array}{c}\text { Estimated } \\ \text { Delta } \\ \text { Coefficient } \\ \text { (a) }\end{array} & \begin{array}{c}\text { Estimated } \\ \text { Delta } \\ \text { Coefficient } \\ \text { (b) }\end{array} & \begin{array}{c}\text { Estimated } \\ \text { Interaction } \\ \text { Coefficient } \\ \text { (c) }\end{array} & \begin{array}{c}\text { Estimated } \\ \text { Average } \\ \text { Effect } \\ \text { (d) }\end{array} & \begin{array}{c}\text { Estimated } \\ \text { Effect Conditional } \\ \text { On Incumbency }\end{array} \\ 1980-1981 & -0.0014 & -0.0015 & 0.00163 & 3.0 \% & (\text { e) } \\ 1981-1982 & 0.01304 & 0.01167 & 0.00103 & 11.3 \% & 4.2 \% \\ 1982-1983 & 0.02731 & 0.00225 & 0.00098 & 8.6 \% & 23.2 \% \\ 1983-1984 & 0.02995 & -0.0097 & 0.00156 & 4.5 \% & 1.1 \% \\ 1984-1985 & 0.02147 & 0.00106 & 0.00199 & 6.7 \% & 19.7 \% \\ 1985-1986 & 0.02684 & -0.0023 & 0.00122 & 5.4 \% & 11.5 \% \\ 1986-1987 & 0.02425 & 0.00173 & 0.0013 & 6.5 \% & 20.5 \% \\ 1987-1988 & 0.00368 & 0.02901 & 0.0006 & 3.3 \% & 49.0 \% \\ 1988-1989 & -0.0227 & 0.03636 & 0.00229 & 2.9 \% & 29.4 \% \\ 1989-1990 & -0.0494 & 0.0134 & 0.0041 & -1.6 \% & 3.4 \% \\ 1990-1991 & -0.0201 & -0.0126 & 0.00634 & -0.3 \% & -8.3 \%\end{array}$

Note: The table reports the estimated coefficients on the collusion indices described in the text. We have estimated the effect of collusion based on the mean values of the variables used in the regression. The results reported in column (d) are the expected markups for all districts over competitive prices, in percent. 